\title{
A Sociological Breakthrough of Interreligious Engagement in Everyday-Symbolic Interaction Perspectives
}

\author{
Izak Lattu \\ Universitas Kristen Satya Wacana, Salatiga \\ lattu@staff.uksw.edu
}

\begin{abstract}
This article explores the symbolic interaction, interfaith daily in Indonesia and beyond. The question of how one can live peacefully in a multireligious environment that has colored a discussion about interfaith engagement in many regions of the world. This article begins with a discussion of interfaith relations by introducing the history of migration in Europe. Having developed an awareness of everyday symbolic in migrant-host relationship, this article studied the effect of migration to interfaith engagement in Europe and the United States. Interfaith engagement in this sense is a means of building peace in many parts of the world, including Indonesia. Based on the sociological context of interreligious relations, the article criticized the rigidity of interreligious dialogue is stuck in the official forums related to religious issues. Therefore, religious dialogue based on everyday relationships become important to create the same sphere where everyone has the same solidarity and understanding with all those who have faith and religion are different.

[Artikel ini mengeksplorasi interaksi simbolis antariman seharihari di Indonesia dan di luar. Pertanyaan bagaimana seseorang dapat hidup secara damai di lingkungan yang multiagama telah mewarnai diskusi tentang keterlibatan lintas agama (interreligious engagement) di banyak wilayah di dunia. Artikel ini dimulai dengan diskusi tentang hubungan antaragama dengan
\end{abstract}


memperkenalkan sejarah migrasi di Eropa. Dengan mengembangkan kesadaran simbolis sehari-hari dalam hubungan migran-tuan rumah, artikel ini mendalami pengaruh migrasi ke keterlibatan antaragama di Eropa dan Amerika Serikat. Keterlibatan antaragama dalam pengertian ini adalah sarana pembangunan perdamaian di banyak bagian dunia, termasuk Indonesia. Berdasarkan konteks sosiologis hubungan antaragama, artikel ini mengkritik kekakuan antaragama yang terjebak dalam forum dialog resmi terkait masalah agama. Oleh karena itu, dialog agama berbasis hubungan sehari-hari menjadi penting untuk menciptakan wilayah yang sama dimana setiap orang memiliki solidaritas dan pemahaman yang sama dengan semua orang yang memiliki iman dan agama yang berbeda.]

Keywords: symbolic interaction, interreligious engagement, migration, interreligious dialogue.

\section{Introduction}

This article analyzes the contribution of inter-religious engagements as a contribution to the construction of contemporary society. The article addresses a critical question: How everyday-symbolic interactions develop the dynamic of religious pluralism practices, namely interreligious encounters? The research touches on Indonesian experiences of interreligious relationships, which appear to show that hopes for mutual understanding in society remains largely unfulfilled, thus posing a challenge to many believers.

The study of interreligious engagement or dialogue is unquestionably compelling nowadays. The issue of religious conflict has led to interreligious and intra-religious conflict across the globe. Although interreligious engagement and conflict happened in the past, an important aspect of the current problem is that the encounter between believers in this borderless world is taking place on a scale unprecedented in the history of human beings. Migrations of people from third world countries to Europe and America have created much diverse pictures of human encounters than in the past. In addition, in the 
twenty-first century, people are saturated with information due to rapid improvements and accessibility afforded by information technology. In this article, I argue that everyday-symbolic interaction and interreligious engagement both rely on values of mutual trust, respect, and tolerance.

\section{Global Change and Everyday-Symbolic Encounter}

The issue of interreligious engagements is not new in academic discourse. However, Since World War II, pluralism has spread wide, influenced by and shaping society's way of thinking. This is particularly true with when people from third world nations that were previously occupied by Europeans for hundreds of years moved to European countries. ${ }^{1}$ These migrations brought new awareness of their neighbors to the European, the awareness that they have to live among people with more different cultures and religions. ${ }^{2}$ For instance, the migrations of Muslims to the United Kingdom, the Netherlands, and France have created a significant Muslim minority within these countries. ${ }^{3}$ Max Farrar, Simon Robinson, Yamin Valli, and Paul Wetherly in their project to observe the relationship between Islam of Asia and their host UK communities, found that migration patterns have changed the country to be more multicultural. Religious and cultural encounters, in this case, could lead either to clashes or to mutual recognition. They criticize Huntington's clash of civilization's concept by arguing that Islam and the West have so many meeting points that create "friendly engagement." ${ }^{\text {" }}$

\footnotetext{
1 Stephen Castles, "Immigration and Asylum: Challenges to European Identities and Citizenship," in The Oxford Handbook of Postwar European History, ed. Dan Stone (New York: Oxford University Press, 2012), 205.

2 Jose Casanova, "Immigration and the New Religious Pluralism: A European Union/United States Comparison," in Democracy and New Religious Pluralism, ed. Thomas Banchoff (New York: Oxford University Press, 2007), 59-60.

3 Ataullah Siddiqui, Christian-Muslim Dialogue in the Twentieth Century (London: Macmillan Press, 1997), 52.

${ }^{4}$ Max Farrar et. al., Islam in The West: Key Issues in Multiculturalism (New York: Palgrave Macmillan, 2012), 3-4.
} 
The interaction with people of different skin colors, traditions, and religions, has created a more plural face of Western society. As a result of this encounter, Western society has become symbolically more multi-religious society. From the perspective of Herbert Mead's concept of symbolic interaction, ${ }^{5}$ this changing situation in Western countries has shaped a new awareness among groups who encounter people from other faiths. Mead's argument is centered on relationships between mind, society, and shared symbols. He critiques Rene Decartes' "cogito ergo sum" as selfishness. For Mead, the Cartesian selfishness traps one in one's personal mind, with human beings understood live within the boundary of the self. In contrast, Mead believes that the relationship between society and the self is necessary, and that shared symbols are the means by which the relationship in forged and fostered. Symbolic interactionism in Mead's thinking requires social communication. ${ }^{6}$ In this sense, the coming of immigrants who have different religions from that of European religions brings about a social fact that the existing religions must share the religious market with religious others. When other religious symbols penetrate the West, social communication needs to be the main tool of interactions between the two entities. Ever since the encounter took place, the interaction has shifted the European paradigm of Christianity from being the dominant religion in the public sphere. ${ }^{7}$ In addition, European Christians, who had supported imperialism and evangelism previously, are concluding that it is impossible to convert all human beings who hold religions other than Christianity. The conversion of John Hicks, initially a fundamentalist who grew to become a prominent figure in the theory of religious pluralism, ${ }^{8}$ illustrates Mead's argument on symbolic interactionism and social communication in Western society. Mead argues that interaction and communication with

\footnotetext{
${ }^{5}$ Herbert Mead, Mind, Self, and Society: From the Standpoint of a Social Behaviorist (Chicago: University of Chicago, 1967), 61.

${ }^{6}$ Ibid., 68.

7 John T.S. Madeley, "Deus ex Machina; Representing God on the stage of the European Union," in Representing Religion in the European Union: Does God Matter?, ed. Lucian N. Leustean (London and New York: Routledge, 2013), 52-56.

${ }^{8}$ John Hick, God Has Many Names (Philadelphia: The Westminster Press, 1982), 14.
} 
other symbols will open new perspectives and attitudes toward the others.'

The encounter brings about a new collective consciousness to Western countries. Collective consciousness in Durkheim's perspective is "the shared mental and moral orientation of societies." the perspective of today's plural world, this means that in the West, the existing religious followers in this sense must share the collective mental and moral orientation with people from other religions. In modern French society, the interaction of Islam and Republic illustrates the transformation of collective consciousness from a singular laicite (secularism) based on the remnants of Christian (Protestant and Catholic) morality, to the accommodation of Islam within the French public sphere. Daniele Hervieu-Leger points out that "many young Muslims claim to live, publicly and collectively, according to an Islam which they have appropriated as a fundamental dimension of their cultural and social identity." 11 The externalization of the Islamic symbol in the public sphere creates a new social mental and morality. Similarly, the United States of America, which developed previously out of a Judeo-Christian foundation, must accommodate the values of newly entering religions, as well as Native American religions, into American public life. Yvonne Haddad and Adair Lummis argue that Islam brings positive value for American society. They show that Muslims who have lived in the USA for a long-time use preaches to inspire the Muslim community to engage peacefully with the host society. ${ }^{12}$ In many public events, the symbol of Islam has already taken its place in American public life. For instance, Muslim students and teachers who dress up in hijab as well as develop mosques by campuses have introduced Islamic symbol to the USA public sphere.

\footnotetext{
${ }^{9}$ Herbert Mead, Mind, Self, and Society, 70-71.

${ }^{10}$ Emile Durkheim, The Division of Labor in Society (New York: Macmillan, 1997), 229.

${ }^{11}$ Daniele Hervieu-Leger, "Islam and the Republic: The French Case," in Democracy and the New Religious Pluralism, ed. Thomas Banchoff (New York: Oxford University Press, 2007), 204.

12 Yvonne Haddad and Adair Lummis, Islamic Values in the United States: A Comparative Study (New York: Oxford University Press, 1987), 31.
} 
The posture of pluralistic society in modern world is the result of globalization of humans, values, and technology. Thomas Friedman divides globalization into three phases: first, colonialism beginning with the era of Columbus; second, migration driven by economic and the expansion of Multi-National Corporations; and third, the development of digital communications and fiber optics cable that created a "flatworld" platform. ${ }^{13}$ Peter Berger sees this encounter as an inevitable process of globalization. "The "new pluralism", of course, is the result of globalization. Almost all societies are today inevitably pluralistic. Globalization has meant an enormous increase in intercultural communication." ${ }^{\text {14 }}$ Accordingly, religious believers in the globalization age need to engage deeply with people of other religions. The encounter may help religious adherents to shape new attitude towards people from other faiths. Thomas Banchoff points out, "new communications technologies not only enable the creation and sustenance of transnational religious communities, thereby sustaining a high degree of religious pluralism in world politics, but also foster an internal diversification of religious traditions." ${ }^{15}$ New communication technologies in the globalization era have improved very rapidly, making the world a "global village."16 Banchoff also adds, "the geographic extension and mobilization of religious communities through communication technologies also deepen their interaction with one another." 17

Indeed, religious dialogue is a key factor in promoting understanding, in which openness and willingness to learn from other religious traditions are central values. Religious scholars, like John Cobb,

13 Thomas L. Friedman, The World Is Flat: a Brief History of The Twenty-First Century (New York: Farrar, Straus dan Giroux, 2006), 8-11.

14 Peter L. Berger, "Pluralism, Protestantization, and the Voluntary Principle," in Democracy and the New Religious Pluralism, ed. Thomas Banchoff (New York: Oxford University Press, 2007), 19.

15 Thomas Banchoff, Religious Pluralism, Globalization, and World Politics (New York: Oxford University Press, 2008), 10.

${ }^{16}$ Lester R. Kurtz, Gods in the Global Village: The World's Religions in Sociological Perspective (Los Angeles: Sage, 2012), 3-5.

17 Banchoff, Religious Pluralism, Globalization, and World Politics, 11. 
Jr., who crossed over to Buddhist teachings, ${ }^{18}$ and Seyyed Hossein Nasr who offered reflections on Islam and religious pluralism to encourage Muslims to go deeper into the terrain of religious others, ${ }^{19}$ are examples of interreligious engagement in this borderless world. Komarudin Hidayat, an Indonesian Muslim scholar, who developed his thinking from the Indonesian pluralistic context, believes that interreligious engagements should be begun with a passing over into other religious terrain. ${ }^{20}$ In Peter Berger's concept, interreligious engagements call for externalization, objectivation, and internalization. ${ }^{21}$ Berger understands externalization as the process of human being physical and mental outpouring into society. Objectivation for him is the human being's acceptance of physical and mental product when human encounters different reality. Internalization in Berger's mind is the transformation of physical and mental reality into the structure of subjective consciousness. ${ }^{22}$ Encounters with religious others is a trigger that moves a religious community to share religious values and beliefs in the public sphere. Each community involved in this encounter engages critically but sympathetically with the understanding of other religions. The encounter, then, creates a new attitude toward other people. The attitude of one person toward people of other religions might vary according to individual perspective and experience, but people who engage with other religious people in a prolonged manner, will have greater potential to build bridges with other religious communities.

\section{Interreligious Engagement Beyond Formal Dialogue}

\footnotetext{
18 John B. Cobb Jr., Beyond Dialogue: Toward a Mutual Transformation of Christianity and Buddhism (Eugene OR: Wipf and Stock Publishers, 1998), 1-10.

19 Seyyed Hossein Nasr, Religion and Religions: The Challenge of Living in the Multireligious World (Charlotte: The University of North Carolina Press, 1985), 63.

${ }^{20}$ Komaruddin Hidayat and Ahmad AF Gaud, Passing Over: Melampuai Batas Agama (Jakarta: Gramedia and Yayasan Paramadina, 1998), 12.

${ }_{21}$ Peter L. Berger, The Sacred Canopy: Elements of a Sociological Theory of Religion (New York: Anchor Books, 1967), 4.

22 Ibid., 4-5.
} 
Scholars differ in their idea of the basics of interreligious engagements or dialogue. Leonard Swidler, who marked interreligious dialogue as a formal process, believes that interreligious dialogue is a set of conversations. After spending years of his academic life on interfaith relationships, Swidler concludes that dialogue (interreligious dialogue) "is conversation between two or more persons with differing views, the primary purpose of which is for each participant to learn from the other so that he or she can change and grow." ${ }^{23}$ Unlike Swilder, Nancy T. Ammerman and Diana Eck agree that interreligious dialogue also develop through everyday entanglements. In Nancy T. Ammerman's perspective, interreligious dialogue can be based on "everyday strategies of action... Those everyday strategies take place not only across cultural and religious traditions but also across the multiple settings in which modern people create a life." ${ }^{24}$ For Eck, dialogue of life or dialogue in community is based on people's daily activities and ordinary relationships. ${ }^{25}$ To borrow from Bourdieu, everyday activities create cultural capital ${ }^{26}$ for interreligious engagements or dialogue. In a given society, everyday activities create a reflective understanding of in-group communication, or doxastic, to use Bourdieu's term. ${ }^{27}$

Diana Eck's dialogue of life or dialogue in community has been tested by J.B. Banawiratma in Indonesia, and Ina Merdjanova and Partice Brodeur in the Balkans. Banawiratma, an Indonesian Catholic scholar who works for interfaith relationships at the grass-roots level, concludes that interfaith engagement is developed on a "common concern. ${ }^{28} \mathrm{He}$

23 Leonard Swidler and Paul Mojzes, The Study of Religion in an Age of Global Dialogue (Philadelphia: Temple University Press, 2000), 151.

${ }^{24}$ Nancy T. Ammerman, ed., Everyday Religion: Observing Modern Religious Lives (New York: Oxford University Press, 2007), 12-13.

25 Diana Eck, Interreligious Dialogue as a Christian Ecumenical Concern (New York: Columbia University Press, 1998), 13.

26 David Swartz, Culture and Power: The Sociology of Pierre Bourdien (Chicago: The University of Chicago Press, 1997), 141.

27 Terry Rey, Bourdieu on Religion: Imposing Faith and Legitimacy (London: Equinox Publishing Ltd., 2007), 51-53.

28 J. B. Banawiratma, "Contextual Theology and the Dialogical Building Blocks of Democracy," in Religious in Dialogue: From Theocracy to Democracy, eds. Alan Race and Ingrid Shafer (Burlington: Ashgate, 2002), 56. 
argues, "in daily life men and women of different religions experience a common situation, with its anxieties and hopes, out of which their common concern emerges." 29 Likewise, Ina Merdjanova and Patrice Brodeur have studied interreligious dialogue for peacebuilding in the Balkans from which they conclude:

A broader definition of interreligious dialogue could be: all forms of human communication both through speech and shared activities that help mutual understanding and cooperation between different people who self-identity religiously. ${ }^{30}$

Jurgen Habermas also believes in the everyday communication for dialogue in a public sphere. For Habermas, "everyday life, however, is a more promising medium for regaining the lost unity of reason than are today's expert cultures of yesteryear's classical philosophy of reason." ${ }^{31}$ Thus everyday communication, in Habermas' perspective "makes possible a kind of understanding that is based on claims to validity and thus furnishes the only real alternative to exerting influence on one another."32

Interreligious dialogue requires the capacity to listen and to learn from other people. By listening and learning, each party in the dialogue has the same opportunity to share and to accept people from other faiths. Irene $\mathrm{Oh}$ argues, "participants in dialogue share equal opportunities to speak and their roles in dialogue are balanced." 33 Dialogue, here, is not necessarily a formal discussion or "high-level, high profile interreligious diplomacy" to quote Appleby. ${ }^{34}$ Marc Gopin insists that formal dialogue belongs to "educated, verbal, and aggressive people in a group encounter. However, people can engage through gestures,

\footnotetext{
${ }^{29}$ Ibid., 57.

30 Ina Merdijanova and Patrice Brodeur, Religion as a Conversation Starter: Interreligious Dialogue for Peacebuilding in the Balkans (New York: Continuum, 2009), 3.

31 Jurgen Habermas, Moral Consciousness and Communicative Action, trans. Christian Lenhardt and Shierry Weber Nicholsen (Cambridge: The MIT Press, 1990), 18.

32 Ibid., 19.

33 Irene Oh, The Rights of God: Islam, Human Rights, and Comparative Ethics (Washington DC: Georgetown University Press, 2007), 18.

34 R. Scott Appleby, The Ambivalence of The Sacred: Religion, Violence, and Reconciliation (Lanham and Oxford: Rowman and Littlefield Publishers, Inc., 2000), 223.
} 
symbols, emotions, and shared work." ${ }^{35}$ At the same time, Mohammad Abu-Nimer believes that participating in the ritual of other religious communities is among the ways one can open horizon of interreligious dialogue and understanding. For Abu-Nimer, "in interfaith dialogue, ritual creates a mode of dialogue. Understanding other religions rituals opens the window onto meaning system of the others." ${ }^{36}$

In the field of religious studies, interreligious engagement needs a mutual understanding that enables religious followers to "cross the rubicon." Drawing on Herbert Mead's symbolic interaction, Habermas develops his communicative action, which is based on mutual understanding. ${ }^{37}$ For Habermas, mutual understanding is a backbone of social interaction "with respect to all other validity claims." ${ }^{38}$ Inspired by Habermas "communicative praxis", Paul Knitter develops an acceptance model for interreligious engagement in the theologies of religions. Knitter says,

...we can take up the challenge of what Jurgen Habermas calls the task of "communicative praxis." To know the truth we must be engaged in the practice of communication with others; that means really talking with and listening to people who significantly different from us. ${ }^{39}$

Paul Knitter's acceptance is different from three other models that proposed by Alan Race; exclusivism, inclusivism, and pluralism. ${ }^{40}$ In exclusivism, no engagements are involved in interreligious

35 Marc Gopin, "The Use of the Word and Its Limits: A Critical Evaluation of Religious Dialogue as Peacemaking," in Interfaith Dialogue and Peacebuilding, ed. David R. Smoch (Washington DC: United States Institute of Peace Press, 2002), 37.

36 Mohammed Abu-Nimer, "The Miracle of Transformation through Interfaith Dialogue: Are You a Believer?," in Interfaith Dialogue and Peacebuilding, ed. David R. Smoch (Washington DC: United States Institute of Peace Press, 2002), 18.

37 Jurgen Habermas, The Theory of Communicative Action Volume Two: Lifeworld and System: A Critiques of Functionalist Reason, trans. Thomas McCarthy (Boston: Beacon Press, 1989), 22-23.

${ }^{38}$ Patrick Baert, Social Theory in the Twentieth Century (New York: New York University Press, 1998), 143.

39 Paul Knitter, Introducing Theologies of Religions (New York: Orbis Books, 2003), 12.

40 Alan Race, Christians and Religious Pluralism: Pattern in Christian Theology of Religions (London: SCM Press, 1983), 14-20. 
relationships. ${ }^{41}$ To sum up, exclusivism provides no room for interreligious engagements because on religion claims while all other religions are seriously wrong. ${ }^{42}$ Inclusivism insists that there is truth and salvation in many religions, but it remains dependent on the perspective of one given religion. For instance, from Christian perspective, Karl Rahner has pointed out that the salvation offered in Jesus Christ is available not only for those who hear Jesus name; thus, saving grace must be universally available in all cultures, without regard to geography or age. ${ }^{43}$ In Islam, the concept of Abl al-Kitab, the "people of the book" is another example of inclusivism. Sociologically, the concept of $\mathrm{Abl}$ alKitab draws a line between groups, namely between the followers of Abrahamic religions and the religions that fall outside this group. Zulfikar Hirji believes that the concept could be a common ground for people from Abrahamic religions:

For example, the category Ahl al-Kitab (People of the Book), while referring to Jews and Christians, also includes Muslims, communities for all of whom a 'messenger' and a 'book' are also central tenets of religious belief. Hence, the category of Ahl al-Kitab marks both difference as well as common ground between these religious groups. ${ }^{44}$

This common ground is a glue to bind, at least, Abrahamic religions into a fruitful interreligious engagement. For scholars like Ernest Gellner, the Islamic perspective of peace comes out of the Islamic blueprint for social order. Through Ibn Kaldun's lens, Gellner perceives an egalitarian position for scriptural communities in Islamic teaching. ${ }^{45}$

${ }^{41}$ Paul Knitter, One Earth Many Religions (New York: Orbis Books, 1995), 33.

42 William Lane Craig, "No Other Name: A Middle Knowledge Perspective on the Exclusivity of Salvation through Christ," in The Philosophical Challenge of Religious Diversity, eds. Philip L. Quinn and Kevin Meeker (New York: Oxford University Press, 2000), 33.

${ }^{43}$ Clark H Pinnock, "An Inclusivist View," in On Salvation in a Pluralistic World, eds. Dennis L. Oklolm and Timothy R. Phillips (Grand Rapids, MI: Zondervan Publishing House, 1995), 99.

${ }_{44}$ Zulfikar Hirji, ed., Diversity and Pluralism in Islam: Historical and Contemporary Discourses Amongst Muslims (New York: A.B. Tauris Publishers, 2010), 6.

${ }^{45}$ Ernest Gellner, Muslim Society (Cambridge: The University of Cambridge, 1981), 1625. 
However, exclusivism and inclusivism, or replacement and fulfillment in Knitter's work, have contributed to shaping an inequality in a given society. To borrow from Frantz Fanon, both exclusivism/replacement and inclusivism/fulfillment have situated other people in the zone of non-being. Frantz Fanon points out that the colonialism of a Western state, France in this case, in an Islamic country, Algeria, positioned the French as the master and the Algerians as the slaves. The colonial power argues that they invaded a zone of nonbeings. Those who stayed in the zone of non-being are seen as having a lack in comparison to the people from the zone of being, the colonial power. ${ }^{46}$ It is hard to imagine mutual engagement in a society where some groups have claimed the position of zone of being while putting another group into the zone of non-being.

Unlike exclusivism and inclusivism, pluralism underlines that all religions have their own salvation. Thus, in the perspective of pluralism, no religion can claim the absolute truth. The guru of religious pluralism, John Hick, proposes that all world religions relate to the Ultimate Reality, but in different ways. ${ }^{47}$ Although pluralism as pioneered by Hick appears as the most advanced means to approach other religions, scholars like Knitter and John Cobb, Jr. have criticized religious pluralism or mutuality for its inability to cross over to the land of religious others. There is no chance to go beyond dialogue because that pluralism or mutuality can only provide the foundation to understand each other's religious basis without going deeper into particular religious teaching. ${ }^{48}$ In his critique, Knitter writes that the pluralism perspective "imposes its own particular viewpoint on all the others in the name of universality." He adds, "mutualists become imperialists." 49 For him, the acceptance model is a more workable foundation for interreligious engagements. ${ }^{50}$ Alwi Shihab, an Indonesian Muslim scholar, agrees that acceptance or, to borrow from John Cobb, Jr., mutual transformation,

\footnotetext{
${ }^{46}$ Frantz Fanon, Black Skin, White Mask (New York: Grove Press Inc, 1963), 26-28. ${ }^{47}$ John Hick, God Has Many Names, 41.

48 John B. Cobb Jr., Transforming Christianity and the World: $A$ Way beyond Absolutism and Relativism (Manchester: The Manchester University Press, 1999), 105.

49 Paul Knitter, Introducing Theologies of Religions, 158.

50 Ibid., 229.
} 
does not stop at peaceful co-existence, but extend to religious people who are able to transform themselves by having an open attitude and by learning from teachings and wisdoms of other religions. ${ }^{51}$

\section{Interreligious Engagement as Peacebuilding}

An intense and genuine communication brings about a true acceptance and deep engagement in interreligious relationships. Brewer, Higgins, and Teeney's study of the peacemaking process in Northern Ireland describes a picture of relationships ranging between solidarity, communication, and interreligious engagement. Their study shows that the absence of communication and commitment based on solidarity creates "mutually exclusive ethno-religious blocs. The lack of communication, even unofficial communication, leads to a conflict transformation rather than social transformation." ${ }^{25}$ In peace studies, John Galtung's concept of negative peace (the absence of war) and positive peace (the existence of mutual engagement) is an important contribution. A negative peace might be overcome by conflict transformation, while social transformation is a result of the positive peace. $^{53}$ For Brewer, Higgins, and Teeney, this active peacebuilding "involves commitment to behaviours, values, beliefs, and discursive formations that put peace into practice, in which peacemaking is habit, custom, and tradition, as well as ideal, in which peace effects the kinds of social relationships." ${ }^{54}$

Where Brewer, Higgins, and Teeney have juxtaposed peacemaking and peacebuilding, Thania Paffenholz goes further in echoing and claiming John Galtung that peacemaking and peacebuilding

51 Alwi Shihab, Islam Inklusif: Menuju Sikap Terbuka dalam Beragama (Bandung: Mizan dan ANTV, 1997), 82.

52 John D. Brewer, Gareth I. Higgins, and Francis Teeney, Religion, Civil Society, and Peace in Northern Ireland (New York: Oxford University Press, 2011), 207.

53 Johan Galtung, Peace by Peaceful Means: Peace and Conflict, Development and Civilization (London: Sage Publications Ltd, 1996), 58.

${ }^{54}$ John D. Brewer, Gareth I. Higgins, and Francis Teeney, Religion, Civil Society, and Peace in Northern Ireland, 32. 
are substantially different. In Paffenholz's understanding of Galtung's peace theory:

\begin{abstract}
Peacemaking in a conflict resolution understanding (discussed later in this chapter) aims at removing the tensions between the conflict parties in addressing the causes of violence. Peacebuilding achieves positive peace by creating structures and institutions of peace based on justice, equity, and cooperation. In consequence, peacebuilding addresses the underlying causes of conflict and prevents their transformation into violence. ${ }^{55}$
\end{abstract}

One can conclude that peacebuilding engages people in positive peace. People from one group can work with other groups because trust and understanding have lasted in the relationship. Thus, peacebuilding might not be achieved only by formal dialogue. Rather, peacebuilding, as Lisa Schirch points out, needs to "engage people through multiple ways of learning and knowing. Peacebuilding ritual allows people to eat, drink, smell, dance, laugh, cry, and express the full range of human emotions... and develop new and creative ways of understanding their conflict." ${ }^{\text {"56 }}$ Schirch also adds singing and holding hands as two major ways to bring the peacebuilding ritual into the practice of understanding and peace. ${ }^{57}$

Everyday activities are also important in the study of peacebuilding and civic engagement. Oliver Richmond and Audra Mitchell have illustrated the significant role and the challenge of everyday activities and agencies in peacebuilding narrative. In their words, "engaging with the everyday in peacebuilding settings simultaneously emancipates and entraps, enriches and depletes, enhance the quality of life and tightens control over it." ${ }^{\text {58 }}$ Everyday forms of peacebuilding, in Richmond and Mitchell's argument provide ample room for local traditions to be the foundation of civic engagements and

55 Thania Paffenholz, Civil Society and Peacebuilding: A Critical Assessment (Boulder: Lynne Rienner Publishers, 2010), 45.

${ }^{56}$ Lisa Schirch, Ritual and Symbol in Peacebuilding (Bloomfield: Kumarian Press, 2005), 164.

57 Ibid., 166.

58 Oliver P. Richmond and Audra Mitchell, eds., Hybrid Forms of Peace: From Everyday Agency to Post-Liberalism (New York: Palgrave Macmillan, 2012), 21. 
reconciliation because everyday peacebuilding creates space for coexistence and understanding among people in a given local community. Richmond and Mitchell also point out that the everyday forms of peacebuilding include women, who often are forced to stay away from formal and verbal peacebuilding processes. Therefore, "the everyday is viewed as the place where plurality and otherness are expressed immediately, without mediation, and in all its variety." ${ }^{59}$ Similarly, John Lederach believes that everyday activities such as song, poetry, and craft can be the means of peacebuilding through imagination and creativity. His study in the Northern Ireland and West Africa describes how collective feelings and emotions move people into recognition and understanding. ${ }^{60}$

In religious based conflict, peacebuilding seeks interreligious engagement that goes beyond mere co-existence. The Peacebuilding in this sense is a way by which religious communities find a pro-existent bond. Peacebuilding therefore, requires positive tolerance. Building from John Galtung's negative and positive peace, Meridjanova and Brodeur divide tolerance into negative tolerance and positive tolerance. They state, "we understand negative tolerance to be a position of pragmatic non-interference and bearing with difference, while positive peace means not just enduring and putting up with religious others, but engaging with respecting the others for the value of their differences." ${ }^{\text {61 }}$ Learning from the Indonesian context, and based on Benedict Anderson's theory of imagined communities, ${ }^{62}$ Bernard T. Adeney-Risakotta, an American Indonesian religious scholar, points out that positive religious engagements, or positive tolerance, brings positive memory as a community that binds people regardless of their religious affiliations. Expanding on Anderson, Adeney-Risakotta believes that positive

\footnotetext{
${ }^{59}$ Ibid., 22.

60 John Paul Lederach, "The Arts and Peacebuilding: Using Imagination and Creativity," in People Building Peace II: Successful Stories of Civil Society, eds. Paul van Tongeren et.al. (Boulder and London: Lynne Rienner Publishers, 2005), 283-287.

${ }^{61}$ Ina Merdjanova and Patrice Brodeur, Religion as a Conversation Starter, 4.

62 Benedict Anderson, Imagined Communities: Reflections on Origin and Spread of Nationalism. Revised Edition (New York and London: Verso, 2006).
} 
memory creates a positive image toward people of other faiths, by which an imagined community is formed. ${ }^{63}$

Religious based peacebuilding leads to interfaith engagement based on common concerns, instead of grounded solely on theological perspectives. From the Islamic perspective, Ahmad Syafii Maarif mentions bringing religious tolerance into factual life, saying, "to move to this direction (respect), all of us should shift our paradigm to the level of spiritual maturity, so the principles of socio-religious tolerance become actually factual." " From Indonesia's context, Maarif's "actually factual" means the concrete social-religious tolerance. Maarifs studies on Indonesian national ideology, Pancasila, conclude that in a diverse and multi-religious country like Indonesia, ideology might function as the shared that incorporate religious communities in the common concern for the nation and the culture of positive tolerance. Thus, he argues strongly that religious communities in a multi-religious country like Indonesia need to locate dialogue in concrete actions. Maarif points out, "the Indonesian interfaith leaders are not only buddies in religion-moral intellectual dialogues, but working on the ground to help enlighten people at the grass-roots level." ${ }^{65}$ The struggle of the Acehnese in the wake of the deadly tsunami that took 200,000 lives is one among many of the situation that started interreligious dialogue based on concrete action. In the case of Aceh, the dialogue in practice, along the lines of post-tsunami reconstructions, helped to alter Aceh Muslims's perceptions of Christians and the West. Using Bryan Turner's perspective, experience as such will shape trustworthiness among communities. Turner argues, "past experience of reliable co-operative interaction tends to enhance our general sense of the trustworthiness of other people in a community."

63 Bernard T. Adeney-Risakotta, "Tangled Memories: Christianity Identity in Indonesia," in Commitment of Faiths: Identity, Pluralism and Gender, ed. Eka Dharmaputra (Yogyakarta: Dian Interfidei and Pustaka Pelajar, 2002), 11-42.

${ }^{64}$ Ahmad Syafii Maarif, Franz Magnis-Suseno, SJ, and Hans Zehermair, Ethics and Religious Dialogue in a Globalized World (Jakarta: The Habibie Center, 2010), 19.

${ }^{65}$ Ibid., 27.

66 Bryan S. Turner, Religion and Modern Society: Citizenship, Secularization and the State (Cambridge: Cambridge University Press, 2011), 164. 
Thania Paffenholz, the experience transforms the image "from the enemy image to a friendly image." ${ }^{67}$

\section{Conclusion}

Interreligious encounter is a timely topic today when the world has become a "global village". The migrations of people and "migration" of information and technology creates a stage where people meet either physically or imaginatively. In this context, interreligious engagement finds its role to build bridges between people from different faiths. The engagement or dialogue could be either formal or non-formal, based on cannons or not depending upon the context in which the engagement or dialogue takes place. From the perspective of sociology of religion, interreligious engagement is a social capital to create better understanding and diminish prejudice and hatred among religious communities and even civilizations.

In everyday interreligious engagement or dialogue, people may employ multiple means of encounter including everyday communication, song, poetry, and ritual performance. Interreligious engagement or dialogue on a daily basis is based on people's ordinary activities and common relationships. Therefore, the engagement includes many people, not only the elite, but also in a given society. As it covers multiple layers and people, everyday interreligious engagement provides room for women and children, who have been excluded from the formal male-dominated dialogue. Therefore, in everyday dialogue, all people are able to share, speak, perform, listen, and understand. In the interfaith peacebuilding process in many countries, everyday interreligious engagement could open the gate of reconciliation and build a genuine and strong interfaith peace. Everyday dialogue needs the common ground of people creating solidarity and mutual understanding among people who hold different beliefs and faiths.

${ }^{67}$ Luc Reychler and Thania Paffenholz, eds., Peacebuilding: a Field Guide (London: Lynne Rienner Publishers, 2001), xiv. 


\section{Bibliography}

Abu-Nimer, Mohammed. "The Miracle of Transformation through interfaith dialogue; Are you a believer?" In Interfaith Dialogue and Peacebuilding, ed. David R. Smoch. Washington DC: United States Institute of Peace Press, 2002.

Adeney-Risakotta, Bernard T. "Tangled Memories: Christianity Identity in Indonesia." In Commitment of Faiths: Identity, Pluralism, and Gender, ed. Eka Dharmaputra, 11-42. Yogyakarta: Dian Interfidei dan Pustaka Pelajar, 2002.

Ammerman, Nancy T. ed. Everyday Religion: Observing Modern Religious Lives. New York: Oxford University Press, 2007.

Anderson, Benedict. Imagined Communities: Reflections on Origin and Spread of Nationalism. Revised Edition. New York and London: Verso, 2006.

Appleby, R. Scott. The Ambivalence of The Sacred: Religion, Violence, and Reconciliation. Lanham and Oxford: Rowman and Littlefield Publishers, Inc., 2000.

Baert, Patrick. Social Theory in the Twentieth Century. New York, NY: New York University Press, 1998.

Banawiratman, J. B. "Contextual Theology and the Dialogical Building Blocks of Democracy." In Religious in Dialogue: From Theocracy to Democracy, eds. Alan Race and Ingrid Shafer. Burlington: Ashgate, 2002.

Banchoff, Thomas. Religious Pluralism, Globalization, and World Politics. New York, NY: Oxford University Press, 2008.

Berger, Peter L. "Pluralism, Protestantization, and the Voluntary Principle." In Democracy and the New Religious Pluralism, ed. Thomas Banchoff. New York, NY: Oxford University Press, 2007.

Berger, Peter L. The Sacred Canopy: Elements of a Sociological Theory of Religion. New York, NY: Anchor Books, 1967. 
Brewer, John D., Gareth I. Higgins, and Francis Teeney. Religion, Civil Society, and Peace in Northern Ireland. New York: Oxford University Press, 2011.

Casanova, Jose. "Immigration and the New Religious Pluralism: A European Union/United States Comparison." In Democracy and New Religious Pluralism, ed. Thomas Banchoff. New York, NY: Oxford University Press, 2007.

Castles, Stephen. "Immigration and Asylum: Challenges to European Identities and Citizenship." In The Oxford Handbook of Postwar European History, ed. Dan Stone. New York, NY: Oxford University Press, 2012.

Cobb Jr., John B. Beyond Dialogue: Toward a Mutual Transformation of Christianity and Buddhism. Eugene OR: Wipf and Stock Publishers, 1998.

- Transforming Christianity and the World: $A W$ ay beyond Absolutism and Relativism. Manchester: The Manchester University Press, 1999.

Craig, William Lane. "No Other Name: A Middle Knowledge Perspective on the Exclusivity of Salvation through Christ." In The Philosophical Challenge of Religious Diversity, eds. Philip L. Quinn and Kevin Meeker. New York, NY: Oxford University Press. 2000.

Durkheim, Emile. The Division of Labor in Society. New York, NY: Macmillan, 1997.

Eck, Diana. Interreligious Dialogue as a Christian Ecumenical Concern. New York, NY: Columbia University Press, 1998.

Fanon, Frantz. Black Skin, White Mask. New York: Grove Press Inc., 1963.

Farrar, Max et. al. Islam in The West: Key Issues in Multiculturalism. New York, NY: Palgrave Macmillan, 2012.

Friedman, Thomas L. The World Is Flat: a Brief History of The Twenty-First Century. New York, NY: Farrar, Straus dan Giroux, 2006. 
Galtung, Johan. Peace by Peaceful Means: Peace and Conflict, Development and Civilization. London: Sage Publications Ltd, 1996.

Gellner, Ernest. Muslim Society. Cambridge: The University of Cambridge, 1981.

Gopin, Marc. "The Use of the Word and Its Limits: A Critical Evaluation of Religious Dialogue as Peacemaking." In Interfaith Dialogue and Peacebuilding, ed. David R. Smoch. Washington DC: United States Institute of Peace Press, 2002.

Habermas, Jurgen. Moral Consciousness and Communicative Action. Trans. Christian Lenhardt and Shierry Weber Nicholsen. Cambridge: The MIT Press, 1990.

Habermas, Jurgen. The Theory of Communicative Action Volume Two: Lifeworld and System: A Critiques of Functionalist Reason. Trans. Thomas McCarthy. Boston: Beacon Press, 1989.

Haddad, Yvonne and Adair Lummis. Islamic Values in the United States: A Comparative Study. New York: Oxford University Press, 1987.

Hervieu-Leger, Daniele. "Islam and the Republic: The French Case." In Democracy and the New Religious Pluralism, ed. Thomas Banchoff. New York, NY: Oxford University Press, 2007.

Hick, John. God Has Many Names. Philadelphia, PA: The Westminster Press, 1982.

Hidayat, Komaruddin and Ahmad AF Gaud. Passing Over: Melampuai Batas Agama. Jakarta: Gramedia and Yayasan Paramadina, 1998.

Hirji, Zulfikar, ed. Diversity and Pluralism in Islam: Historical and Contemporary Discourses Amongst Muslims. New York, NY: A.B. Tauris Publishers, 2010.

Knitter, Paul. Introducing Theologies of Religions. New York, NY: Orbis Books, 2003.

Knitter, Paul. One Earth Many Religions. New York, NY: Orbis Books, 1995. 
Kurtz, Lester R. Kurtz. Gods in the Global Village: The World's Religions in Sociological Perspective. Los Angeles, LA: Sage, 2012.

Lederach, John Paul. "The Arts and Peacebuilding: Using Imagination and Creativity." In People Building Peace II: Successful Stories of Civil Society, eds. Paul van Tongeren et.al. Boulder and London: Lynne Rienner Publishers, 2005.

Maarif, Ahmad Syafii, Franz Magnis-Suseno, SJ, and Hans Zehermair. Ethics and Religious Dialogue in a Globalized World. Jakarta: The Habibie Center, 2010.

Madeley, John T.S. "Deus ex Machina: Representing God on the stage of the European Union." In Representing Religion in the European Union; Does God Matter?, ed. Lucian N. Leustean. London and New York: Routledge, 2013.

Mead, Herbert. Mind, Self, and Society: From the Standpoint of a Social Behaviorist. Chicago: University of Chicago, 1967.

Merdijanova, Ina and Patrice Brodeur. Religion as a Conversation Starter: Interreligious Dialogue for Peacebuilding in the Balkans. New York, NY: Continuum, 2009.

Nasr, Seyyed Hossein. Religion and Religions: The Challenge of Living in the Multireligious World. Charlotte: The University of North Carolina Press, 1985.

Oh, Irene. The Rights of God: Islam, Human Rights, and Comparative Ethics. Washington DC: Georgetown University Press, 2007.

Paffenholz, Thania. Civil Society and Peacebuilding: A Critical Assessment. Boulder: Lynne Rienner Publishers, 2010.

Pinnock, Clark H. "An Inclusivist View." In On Salvation in a Pluralistic World, ed. Dennis L. Oklolm and Timothy R. Phillips. Grand Rapids, MI: Zondervan Publishing House, 1995.

Race, Alan. Christians and Religious Pluralism: Pattern in Christian Theology of Religions. London: SCM Press, 1983. 
Rey, Terry. Bourdieu on Religion: Imposing Faith and Legitimacy. London: Equinox Publishing Ltd., 2007.

Reychler, Luc and Thania Paffenholz, eds. Peacebuilding: a Field Guide. London: Lynne Rienner Publishers, 2001.

Richmond, Oliver P. and Audra Mitchell, eds. Hybrid Forms of Peace: From Everyday Agency to Post-Liberalism. New York, NY: Palgrave Macmillan, 2012.

Schirch, Lisa. Ritual and Symbol in Peacebuilding. Bloomfield: Kumarian Press, 2005.

Shihab, Alwi. Islam Inklusif: Menuju Sikap Terbuka dalam Beragama. Bandung: Mizan dan ANTV, 1997.

Siddiqui, Ataullah. Christian-Muslim Dialogue in the Twentieth Century. London: Macmillan Press, 1997.

Swartz, David. Culture and Power: The Sociology of Pierre Bourdieu. Chicago: The University of Chicago Press, 1997.

Swidler, Leonard and Paul Mojzes. The Study of Religion in an Age of Global Dialogue. Philadelphia, PA: Temple University Press, 2000.

Turner, Bryan S. Religion and Modern Society: Citizenship, Secularization and the State. Cambridge: Cambridge University Press, 2011. 